\title{
Penguasaan Fakta, konsep, Prosedur dan Metakognisi melalui Pertanyaan di Pembelajaran Problem Based Learning Biologi
}

\author{
SRI WIDORETNO, SAJIDAN, MURNI RAMLI, JOKO ARIYANTO, \\ SLAMET SANTOSA, ATIKA GURITNA AYU \\ Pendidikan Biologi FKIP Universitas Sebelas Maret Surakarta \\ *email: widoretnosri@gmail.com
}

Manuscript received: 8 September 2015 Revision accepted: 8 Januari 2016

\begin{abstract}
Penelitian bertujuan mengetahui pengaruh pembelajaran problem based learning terhadap penguasan fakta, konsep, prosedur dan metakognisi pada pembelajaran problem based learning pada pelajaran biologi. Penelitian merupakan quasi eksperiment dengan populasi penelitian adalah peserta didik kelas 10 SMAN 4 Surakarta, dengan 2 kelas sebagai sampel penelitian kontrol dan perlakuan. Penentuan sampel menggunakan purposive random sampling untuk dua kelas yang mempunyai kesamaan kemampuan dengan uji $\mathrm{F}_{(32 ; 0,05)}=3$,998. Analisis pertanyaan peserta didik sebelum dan sesudah menggunakan pembelajaran problem based learning menggunakan kualifikasi pertanyaan berdasarkan Taksonomi Bloom. Data dianalisis dengan anacova. Hasil penelitian menunjukan bahwa pembelajaran problem based learning mempengaruhi penguasaan pertanyaan ditinjou dari jumlah pertanyaan pada pengetahuan fakta, konsep, prosedur namun tidak untuk metakognisi.
\end{abstract}

Keywords: problem based learning, pertanyaaan, fakta, konsep, prosedur, metakognisi

\section{LATAR BELAKANG}

Rumah, lingkungan dan sekolah merupakan stimulus untuk belajar yang bermanfaat untuk pendewasaan individu dalam rangka menghadapi dan menyelesaikan masalah di era globalisasi yang sarat dengan kompleksitas: sosial, kultural, ekonomi politik yang berdampak pada metodologi instruksional di pendidikan (McFarlane, 2013). Metodologi instruksional dalam pembelajaran merupakan stimulus belajar yang berupa interaksi antara guru dengan peserta didik dan antara peserta didik melalui media, ceramah, penjelasan dan tanya jawab yang tersusun dalam satu rangkaian pembelajaran dalam bentuk model pembelajaran, salah satunya adalah problem based learning (PBL). Pemanfaatan PBL dalam pembelajaran merupakan bagian dari pendidikan untuk memperbaiki keterampilan yang diperlukan di abad 21 yang bermanfaat menyelesaikan tantangan di era globalisasi (Ravits, et al, 2012). Berbagai macam keterampilan yang diperlukan untuk menghadapi tantangan di abad 21 menurut Silva (2008); Darling-Hammond, (2010) adalah berpikir ekspert dan kompleks, yang keduanya memerlukan proses berpikir tingkat tinggi/High Order Thinking (HOT), sebagaimana dinyatakan oleh Osborne (2013) yang menyatakan bahwa keterampilan berpikir yang diharapkan di abad 21 adalah berpikir: analisis, sintesis dan evaluasi. Keterampilan dasar yang diperlukan di abad 21, selain keterampilan berpikir, adalah: komunikasi oral dan tulisan, berpikir kritis dan pemecahan masalah, profesionalisme dan etika kerja, team work dan kerjasama, adaptasi dengan berbagai kelompok, pemanfaatan teknologi, managemen dan kepemimpinan (Trilling \& Fadel, 2009). Dengan demikian PBL adalah pembelajaran yang dapat mengakomodasi untuk memenuhi kebutuhan di era globalisasi, karena proses merupakan latihan yang membuat semua peserta didik terlibat aktif secara fisik dan psikis yang terlihat dengan pertanyaannya.

PBL adalah pembelajaran yang mempunyai tahapan: 1) meeting the problem; 2) problem analiysis and learning issuees; 3) discovery and reporting, solution presentation and reflection; 4) overview, integration and evaluation (Tan, 2003). Setiap tahapan PBL mempunyai tingkatan kesulitan yang berbeda, namun tahapan yang paling sulit dilakukan dalam pemanfaatan PBL adalah meeting the problem, karena masalah yang dipergunakan sebagai bahan pembelajaran adalah masalah kompleks yang mengandung banyak elemen ilmu yang berperan untuk menjelaskan suatu fenomena alam ataupun kejadian, hal ini seperti dinyatakan oleh Chin \& Chia (2005), yang menyatakan bahwa kesulitan peserta didik belajar dengan menggunakan pembelajaran PBL adalah menentukan prolem yang tidak jelas (ill strukture) dalam bidang biologi, yang mana kesulitan peserta didik diatasi dengan banyak diskusi bersama teman atau keluarga. Berdasarkan kesulitan menemukan pertanyaan atau masalah yang ill structure di saat pertama belajar, ada situasi yang memaksa peserta didik bertanggungjawab untuk berkomunikasi dan berdiskusi dengan orang lain di waktu memulai pembelajaran, sehingga menjadi dasar terbentuknya keterampilan berkomunikasi dan menjalin net-working seperti yang diharapkan di era globalisasi, hal ini didukung oleh Gillies, et al., (2012) yang menyatakan bahwa pertanyaan peserta didik dalam proses investigasi, berperan pada proses berpikir kreatif dengan menjelaskan ide dan pengalaman baru, mengembangkan pemahaman baru untuk memecahkan masalah. Pertanyaan memainkan peran penting dalam belajar bermakna dan berinvestigasi melalui inkuiri yang menjadi sumber potensial untuk belajar dan mengajar, sehingga setiap tahapan PBL memuat inkuiri 
yang perlu diselesaikan oleh peserta didik yang melatihkan keterampilan berpikir, karena struktur pertanyaan terdapat dalam operasional berpikir kritis, krative dan pemecahan masalah (Chin \& Osborne, 2008).

Pertanyaan adalah keterampilan yang merupakan kompetensi yang berperan sentral terhadap proses belajar mengajar karena belajar, berpikir dan partisipasi peserta didik tergantung pada macam dan formulasi pertanyaan guru dalam kelas (Albergaria-Almeida, 2010). Formulasi pertanyaan guru dalam kelas menjadi pemindah pembelajaran yang semula berpusat pada guru menjadi pembelajaran yang berpusat pada peserta didik (Albergaria-Almeida, 2012). Masalahnya adalah penentuan jenis dan macam pertanyaan sebagai pemindah keterpusatan pembelajaran, karena dalam pembelajaran PBL, banyak sekali pertanyaan yang dilakukan mulai dari yang sederhana sampai dengan yang kompleks. Kesulitan untuk menentukan jenis dan macam pertanyaan proses berpikir yang mampu memindahkan pusat pembelajaran kepada peserta didik, ditandai dengan pertanyaan yang termasuk dalam HOT, hal ini didukung Leite, et al. (2011), yang menyatakan bahwa pertanyaan pada level berpikir tinggi di thema dan obyek yang kompleks di sekitar kehidupan adalah permulaaan dari pembelajaran PBL.

Pertanyaan pada thema yang kompleks memerlukan organisasi pengetahuan dan proses selama proses pembelajaran, sehingga menimbulkan interaksi langsung dengan obyek yang dipelajari, hal ini didukung oleh Argote \& Miron-Spektor (2011) yang menyatakan bahwa mengorganissi belajar pada pengalaman yang kontekstual dapat menjadi dasar terbentuknya pengetahuan. Pertanyaan dalam proses pembelajaran secara umum dipergunakan sebagai alat penilaian terhadap penguasaan pengetahuan yang dipelajari, sementara pengetahuan terdiri dari: dimensi fakta, konsep, prosedur dan metakognisi dalam berbagai jenjang proses berpikir (Anderson \& Krathwohl, et al., 2001) yang didalam pertanyaan memuat kualitas proses berpikir, namun tujuan penelitian ini tidak pada kualitas melainkan pada kuantitasnya. Kuantitas pertanyaan adalah bentuk partisipasi peserta didik yang terlibat secara phisik dan psikis dalam mendapatkan pengetahuan baru. Analisis pertanyaan secara kualitatif sebagai pendukung penelitian menunjukan bahwa pada saat sebelum menggunakan pembelajaran PBL, pertanyaan di semua dimensi pengetahuan lebih banyak dijumpai pada tingkatan proses berpikir rendah, hal ini didukung Cardoso \& Albergaria-Almeida, (2014) yaang menyatakan secara umum bahwa proses berpikir tinggi jarang sekali dilakukan oleh peserta didik.

Sementara itu, pertanyaan peserta didik, adalah bentuk visualisasi dari penguasaan pengetahuan, seperti dinyatakan oleh Chin \& Osborne (2008), yang menyatakan bahwa pertanyaan peserta didik merupakan proses berpikir untuk menunjukan ide yang dipikirkan untuk dipresentasikan dan dicoba menghubungkannya dengan pengetahuan yang telah dimilikinya, sebagai contoh adalah untuk mengunkapkan pengetahuan dimensi fakta, dilakukan dengan pertanyaan yang berhubungan dengan proses mengamati fenomena alam atau kejadian, demikian juga untuk konsep, prosedur dan metakognisi. Sesuai dengan filsafat konstruktivisme pengetahuan atau konsep adalah hasil konstruksi manusia melalui interaksi obyek, fenomena, pengalaman dan lingkungannya (Madhuri, et al., 2012), sehingga pengetahuan semua dimensi merupakan produk interaksi dengan semua yang mampu diobservasi oleh peserta didik. Madhuri, et al., (2012) menyatakan bahwa hasil proses belajar yang melibatkan pengolahan informasi adalah berbicara, menulis, interaksi laborasi, yang salah satunya dapat diidentifikasi dari pertanyaan peserta didik.

\section{METODE}

Penelitian merupakan quasi eksperiment dengan rancangan penelitian menggunakan Pretest-posttest Non-equivalent Control Group Design (Sugiyono, 2013). Populasi penelitian adalah peserta didik yang mempunyai kemampuan rata-rata yaitu SMA N 4. Penentuan sampel sebanyak 2 kelas yang mempunyai kesamaan kemampuan menggunakan purposive random sampling berdasarkan uji $\mathrm{F}$, dengan sig $<0.05$. Prosedur penelitian dimulai dengan pengamatan pembelajaran untuk menentukan pertanyaan peserta didik sebelum pelaksanan pembelajaran dengan menggunakan PBL dan pengamatan pada ahkir pembelajarn PBL. Pembelajaran di kelas perlakuan dilakukan sebanyak 12 kali pertemuan untuk 4 tahapan PBL yang berulang. Analisis pertanyaan berdasarkan pada masing-masing dimensi pengetahuan berdasarkan pada Anderson \& Krathwohl, et al., (2001). Skor rerata diperoleh dari penjumlahan semua yang ditemukan di setaip dimensi dibagi dengan pengulangan pembelajaran. Perhitungan dianalisis menggunakan analisis Multivariate Analysis of Variance (Manova).

\section{HASIL DAN PEMBAHASAN}

Hasil penelitian untuk pengetahuan dimensi fakta, konsep, prosedur dan metakognisi seperti pada Gambar 1, 2, 3 dan 4. Gambar 1 menunjukan ada peningkatan pertanyaan faktual di kelas perlakuan dan hasil analisis menunjukan $\mathrm{F}=47.276$, dengan $(\mathrm{p}<0.05)$ dan sig. 0.00, dengan demikian pertanyaan faktual meningkat signfikan, pertanyaan pada dimensi konseptual terlihat pada Gambar 2.

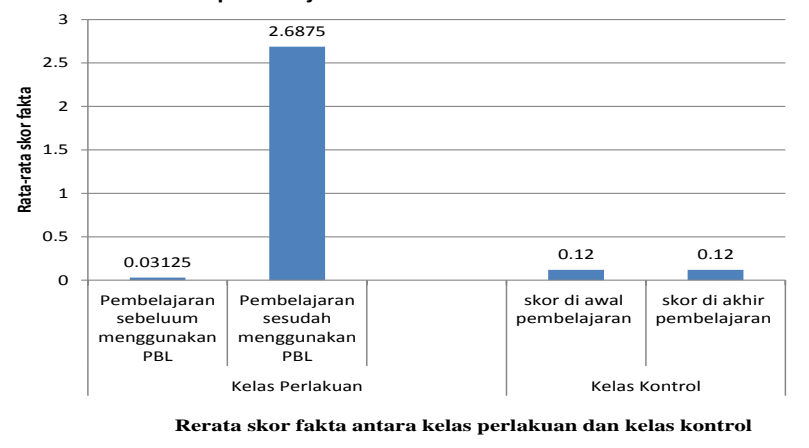

Gambar 1. Pertanyaan Faktual pada saat Sebelum dan Sesudah Perlakuan di Kelas Perlakuan dan Kelas Kontrol 


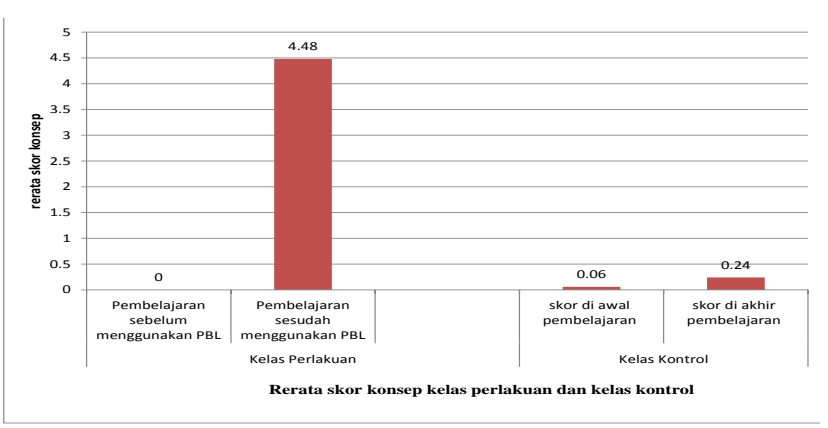

Gambar 2. Pertanyaan Konseptual pada Saat Sebelum dan Sesudah Perlakuan di Kelas Perlakuan dan Kelas Kontrol

Gambar 2 menunjukan ada peningkatan pertanyaan konseptual di kelas perlakuan, dan hasil analisis menunjukan $\mathrm{F}=39.355$, dengan $(\mathrm{p}<0.05)$ dan sig. 0.00 , dengan demikian pertanyaan konseptual meningkat signfikan, sedangkan pertanyaan pada dimensi prosedur terlihat pada Gambar 3 .

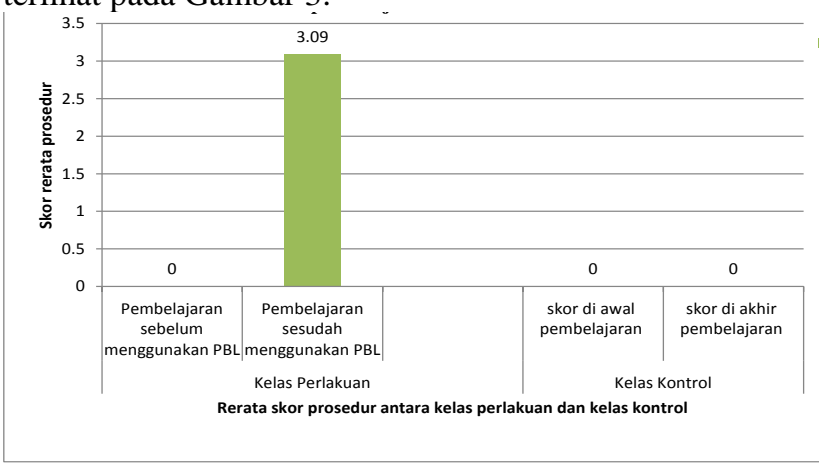

Gambar 3. Pertanyaan Prosedural pada saat Sebelum dan sesudah Perlakuan di Kelas Perlakuan dan Kelas Kontrol

Gambar 3 menunjukan ada peningkatan pertanyaan proseduural di kelas perlakuan dan hasil analisis menunjukan $\mathrm{F}=37.209$, dengan $(\mathrm{p}<0.05)$ dan sig. 0.00 , dengan demikian pertanyaan prosedural meningkat signfikan, untuk pertanyaan pada dimensi metakognisi terlihat pada Gambar 4.

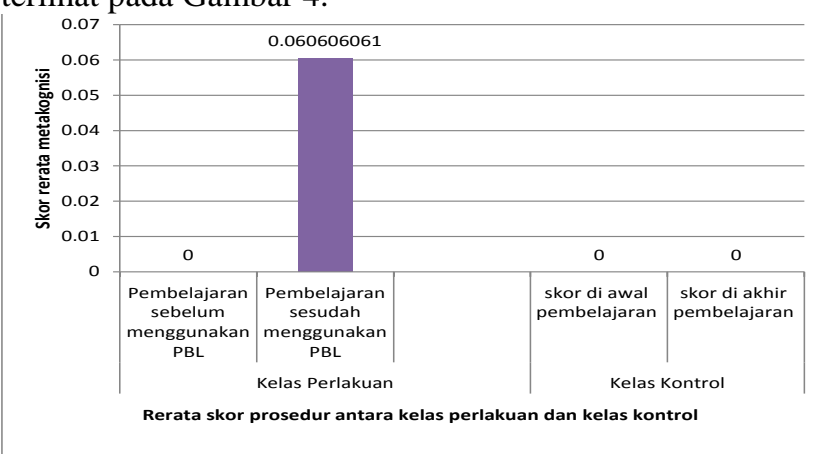

Gambar 4. Pertanyaan Metakognisi pada saat Sebelum dan Sesudah Perlakuan di Kelas Perlakuan dan Kelas Kontrol

Gambar 4 menunjukan ada peningkatan pertanyaan metakognisi di kelas perlakuan, namun hasil analaisis menunjukan $\mathrm{F}=1.000$, dengan $(\mathrm{p}>0.05)$ dan sig. 0.321, peningkatan yang terjadi tidak signifikan. Peningkatan pertanyaan pada pengetahuan di semua dimensi fakta, konsep, prosedur dan metakognisi sebelum dan sesudah perlakuan di kelas perlakuan dan kelas kontrol terlihat di gambar 5 berikut.

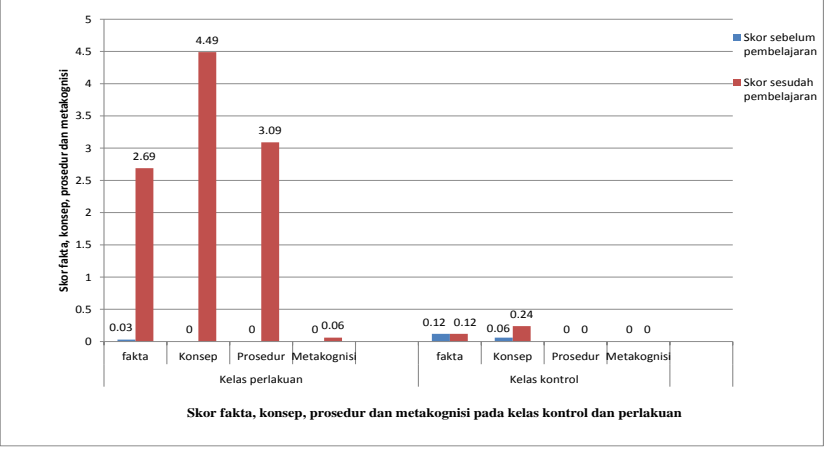

Gambar 5. Pertanyaan Fakta, Konsep, Prosedur dan Metakognisi pada saat Sebelum dan Sesudah Perlakuan di Kelas Perlakuan dan Kelas Kontrol.

\section{Pembahasan}

Berdasarkan hasil analisis statistik untuk pertanyaan peserta didik pada pengetahuan dimensi fakta, konsep, prosedur mengalami peningkatan yang signifikan sedangkan tidak signifikan untuk metakognisi, artinya secara umum pertanyaan dipengaruhi oleh pembelajaran PBL, kecualai untuk metakognisi yang tidak menunjukan perbedaan yang signifikan. Peningkatan pertanyaan secara berturut-turut dari jumlah terbesar ke terkecil adalah konseptual, prosedural, faktual dan metakognisi. Tan (2004) menyatakan bahwa pertanyaan dalam PBL mempunyai peran terhadap proses berpikir: mengingat, memahami, menggunakan, menganalisis, mengevaluasi dan mencipta sesuai dengan Anderson \& Krathwohl, et al. (2001) yang masing-masing mempunyai peran yang berbeda. Pernyataan Tan (2004) meliputi proses berpikir, sedangkan dimensi pengetahuan tidak dijelaskan secara detail.

Peningkatan pertanyaan pengetahuan fakta, konsep dan prosedur disebabkan beberapa hal: 1) PBL adalah pembelajaran dengan thema yang kontekstual dan meliputi berbagai macam jenis pengetahuan bidang ilmu; 2) PBL adalah pembelajaran yang dimulai dengan permasalahan atau pertanyaan yang kompleks mengenai thema yang dipelajari (Tan, 2004); 3) Pertanyaan atau masalah memerlukan penyelesaian melalui investigasi, sehingga dengan standar untuk melakukan investigasi di semua tahapan, memungkinkan pertanyaan dalam semua dimensi pengetahuan juga meningkat. 4) pengetahuan fakta, konsep dan prosedur merupakan pengetahuan yang langsung dikonstruksi dari fakta atau obyek yang diamati, sedangkan pengetahuan metakognisi memerlukan treatmen yang spesifik yang memerlukan penelitian lanjutan.

Batasan pertanyaan dalam pembelajaraan adalah proses berpikir dalam belajar, seperti yang yang dinyatakan Chin \& Osborne (2008), pertanyaan adalah proses berpikir yang didalamnya memuat operasional berpikir kritis, kreatif, dan pemecahkan masalah, serta mengindikasikan proses berpikir tentang ide yang dipresentasikan yang mempunyai hubungan dengan pengetahuan yang telah 
dimiliki. Berdasarkan batasan dan makna tentang pertanyaan peserta didik dalam proses pembelajaran, maka pertanyaan peserta didik mengindikasi kedalaman tentang penguasaan fakta, konsep, prosedur dan metakognisinya.

Pembelajaran PBL adalah pembelajaran yang memenuhi standar untuk investigasi karena dalam tahapan meeting the problem; problem analiysis and learning issuees, discovery and reporting, solution presentation and reflection; serta overview, integration and evaluation (Tan, 2003) merupakan tahapan yang memuat inkuiri, sementara dalam proses inkuiri memerlukan investigasi. Investigasi inkuiri mengakomodasi munculnya pertanyaan secara maksimal (Madhuri, et al., 2012). Chin \& Osborne (2008), menyatakan bahwa pertanyaan peserta didik mempunyai peran yang penting dalam belajar bermakna dan berinkuiri. Pertanyaan adalah masalah dalam investigasi research (Borich, 2006). Pertanyaan adalah inti dari inkuiri (Borich, et al., 2006; Ben-David \& Zohar, 2009; AlbergariaAlmaide, 2010), artinya dalam PBL mengakomodasi inkuiri yang lebih dalam, sehingga dengan menggunakannya dalam pembelajaran dapat dipastikan pada semua tahapan terjadi peningkatkan pertanyaan pada fakta, konsep dan prosedur, dikarenakan dalam PBL terdapat kedalaman berinkuiri. Pernyatan yang sama dilakukan oleh Chin \& Chia (2005) yang menyatakan bahwa PBL adalah multiple inkuiri, sedangkan Bell, 2010, menyatakan bahwa PBL adalh multi strategi.

Selain itu, peningkatan pertanyaan pada dimensi fakta, konsep dan prosedur dimungkinkan karena organisasi pembelajaran yang kontekstual yang merupakan interaksi antara obyek yang dipelajari dengan pengetahuan (Argote \& Miron-Spektor, 2011). Instruksi atau pertanyaan guru yang menggunakan pengalaman hidup yang nyata di kehidupan sehari-hari merupakan pertanyaan yang kontekstual yang mempercepat pemahaman konsep yang dikuasai peserta didik (Rivet \& Krajcik, 2008). Kondisi sebaliknya terjadi pada pembelajaran konvensional, yang menujukkan $80 \%$ waktu pembelajaran didominasi oleh pertanyaan guru, sedangkan pertanyan yaang dimunculkan guru merupakan pertanyaan pada level berpikir rendah karena mengutamakan penggalian memori (Johnson \& Adam 2011). Dominansi waktu oleh guru dan rendahnya level pertanyaan yang disampaikan guru, tidak menjadi pemindah keterpusatan pembelajaran.

Peningkatan pertanyaan peserta didik disebabkan juga karena variasi yang heterogen untuk usia, intelektualitas, komunitas belajar dalamlingkungan, hal ini sesuai dengan Cordozo \& Albergaria-Almeida (2012) yang menyatakan bahwa pengetahuan sebelumnya, pengalaman dan keterampilan, usia, karakter guru, tipe guru membelajarkan peserta didik, kondisi akademik kelas, pola interaksi dan topik dapat berperan terhadap jumlah pertanyaan peserta diidik. Sementara itu kompetensi generik seperti: percaya diri, mengevaluasi diri, kemampuan kerjasama dan toleransi, keterampilan komunikasi dan motivasi, berpikir kritis dapat meningkat dengan pemanfaatan PBL (Adnan, et al., 2011). Dampak meningkatnya kompetensi generik adalah meningkatnya interaksi antar peserta didik khussusnya pada keterampilan interpersonal dan komunikasi, sebagai akibat dari interakasi dalam team work, presentasi, mempertanggungjawabkan perencanaan yang disusun, penilaian, interaksi dengan tutor, teman, dan ahli lain.

Peningkatan pertanyaan pengetahuan metakognisi yang tidak signifikan disebabkan karena: 1) guru tidak mempunyai kemampuan cukup untuk melatihkan pertanyaan dalam pengetahuan metakognisi, karena kemampuan metakognisi guru menjadi faktor yang berperan terhadap aktivitas untuk menyusun pertanyaan pada dimensi metakognisi (Albergaria-Almeida, 2012), untuk melatihkan pengetahuan metakognisi langkah pertama yang diperlukan adalah membandingkan dua kenyataan yang kontras (Tanner, 2012); 2) pertanyaan pada pengetahuan metakognisi memerlukan pengetahuan yang dikontruk dari faktual, konseptual dan prosedural yang meningkat secra linier, namun hasil analisis menunjukan bahwa pertanyaan pada ketiganya tidak menunjukan pengetahuan yang dibangun peserta didik berdasarkan pada fakta, sementara untuk membangun metakognisi diperlukan pengamatan terhadap fakta pada thema yang kontekstual. Tanner (2012) menyatakan, untuk melatihkan pengetahuan metakognisi langkah pertama yang diperlukan adalah membandingkan dua kenyataan yang kontras (Tanner, 2012). Kekontrasan antara dua hal yang berbeda ditemukan pada kompleskitas thema yang dipelajari, yang memerllukan persiapan dan kemampuan guru. Persiapan guru nampak pada organisasi materi yang tertulis di rencana pembelajaran yang disusun sebelumnya. Organisi materi dan design yang disusun guru mempengaruhi proses dan produk pembelajaran (Argote, L. \& Miron-Spektor, E. 2011).

\section{KESIMPULAN}

Pertanyaan peserta didik pada dimensi fakta, konsep, prosedur dan metakognisi pada pembelajaran PBL menunjukan penguasan pengetahuan pada dimensinya bervariasi dalam kuantitasnya, sehingga mengidentifikasi partispasi fisik dan psikis peserta didik dalam pembelajaran.

\section{DAFTAR PUSTAKA}

Anderson, L.W., Krathwohl, DR., Airasian, PW., Cruikshank, KA., Mayer, RE., Pintrich, PR., Raths, J., \& Wittock MC. (2001). A Taxonomy for Learning, Teaching and Assessing. A Revision of Bloom's taxonomy of Educational obyective. USA: Addison Wesley Longman, Inc.

Adnan, N.A., Koromiah, W., Abdullah, W., Awang, Y., Would problem based learning affect student' generic competencies? African Journal of Education and Technology. Vol. 1 (3): 1-14.

Albergaria-Almeida. (2010). Questioning patterns and teaching strategies in secondary education. Procedia Social and Behaviour Science. (2): 751-756.

Albergaria-Almeida. (2012). Can I ask a question? the importance of classroom questioning. Procedia Social and Behaviour Science. (31): 634-638. 
Argote, L. \& Miron-Spektor, E. 2011. Organizational Learning: From Experience to Knowledge. Organization Science Vol. 22(5): 1123-1137.

Bell. S. (2010). Project-Based learning for the 21 st Century: Skills for the future. The Clearing House. 83. 39-43. ISSN: 0009-8655 print. DOI: 10.1080/00098650903505415.

Ben-David, A., \& Zohar, A., (2009). Contribution of Metastrategic Knowledge to Scientific Inquiry Learning. International Journal of Science Education. Vol 31(12): 1657-1682.

Borich, G.D. (2006). Introdution to Thingking Skills. Ong, AC., Borich (Eds). Tea-ching Strategies that Promote Thingking Model and Curriculum Appoaches. Singapore: McGrawHill.

Borich, GD., Hao, YW., Aw, WL. (2006). Inquiry-based Learning: A Practical Appli-cation. Ong, AC., Borich (Eds). Teaching Strategies that Promote Thingking Model and Curriculum Aprpoaches. Singapore: McGraw-Hill Borich Thing-king skills.

Cardoso, M.J., \& Albergaria-Almeida, P. (2014). Fostering student questioning in the study of photossyntesis. Procedia Social and Behaviour Science. (116): 3376-3780.

Chin, C. \& Chia, LG. (2005). Problem-Based Learning: Using Ill-Structured Problems in Biology Project Work. Wiley InterScience. DOI 10.1002/sce.20097

Chin, C. \& Osborne, J. (2008). Students' questions: a potential resource for teaching and learning science. Studies in Science Education, 44:1, 1-39, DOI:10.1080/03057260701828101

Darling-Hammond, L. \& Adamson, F. (2010). Beyond basic skills: The role of performance assessment in achieving 21 st century standards of learning. Stanford, CA: Stanford University, Stanford Center for Opportunity Policy in Education.

Farlane, DA. (2013). Understandng the challenges of Science Education in the $21^{\text {st }}$ Century: New Opportunities for Scientifik Literacy. International Letter of Social and Humanistic Science. ISSN 2300-2697. (4): 35-44.

Gallager, S.A. \& Gallagher, J.J. (2013). Using Problem based learning to Explore Unseen Academic Potensial. Interdesiplinary Journal of Problem_based Learning. 7 (1).

Gillies, R.M., Nicholls, K. Burg, G. Haynes, M. (2012). The effect of two strategic and meta-cognitive questioning appoaches on children's explanatory behaviour, problem-solving, and learning durung cooperative, inquiry-based science. International journal of Educational Research. 53: 93-106.

Johnson, L. \& Adam, S. (2011). Challenge Based Learning: The Report from from the Implementation Project Austin. Texas: The New Media Conxsortium.

Leite, L., Dourado, L., \& Morgado, S. (2011). "Science textbooks as questioning and problem-based teaching and learning promoters: change or continuity?". Proceedings of the $15^{\text {th }}$ Biannual of the ISATT - Back to the future. Legacies, continuities and changes. in educational policy, and practice and research. Braga: University of Minho, pp. 1190-1198.
Madhurri, GV., Kantareddi, V.S.S.N. \& Goteti, L.N.S.P. (2012). Promoting higher order thiking skills using inquiry-based learning. European Jurnal of Engineering Education. Vol.37(2).

Osborne, J. (2013). The $21^{\text {st }}$ century challenge for science education:Assessing scientific. Thinking skills and creativity (10): 265-279.

Rivet, AE., \& Krajcik, J.S. (2008). Contextualizing Instruction: Leveraging Students' Prior Knowledge and Experiences to Foster Understanding of Middle School Science. Journal of Reseach in Science Teaching. Vol. 45(1): 79-100.

Ravits, J., Hixson, N., Englidh, M., \& Mergendoller, J. (2012). Using project based learningto teach 21 century skills: Fin dings from a statewide initiative.Annual Meetings of the $A$ merican Educational Research Association.

AERA - Vancouver

Silva, E. (2009). Measuring Skills for $21^{\text {st }}$ Century Learning. Designing ssessments that measure newly important skills presents challenges, but that should not be an excuse for failing to evaluate what students know and are able to do. Washington: Phi Deslta Kappan.

Sugiyono. (2013). Metode Penelitian Pendidikan pendekatan Kuantitatif, Kualitatif, dan R\&D. Bandung: Alfabeta.

Trilling, B. \& Fadel, C. (2009).21 st century skills learning for live in our times. San Francisco:Jossey -Bass.

Tan, O S. (2003). Problem-Based Learning Innovation: Using Problems to Power Learning in the $21^{\text {st }}$ Century. Singapore: Cengage Learning Asia Pte Ltd (p. 1-14).

Tan, OS. Eds. (2004). Enhancing Thinking trough ProblemBased Learniing Approaches. Singapore: SBN 981-243$718-5$

Tan, OS. (2006). Problem Based-Learning pedagogies: Psychological processes enhancement of intelligences. APERA Conference 